\title{
Micromonospora zeae sp. nov., a novel endophytic actinomycete isolated from corn root (Zea mays L.)
}

\author{
Yue Shen ${ }^{1,2,5}$, Yuejing Zhang ${ }^{3,5}$, Chongxi Liu ${ }^{3}$, Xiangjing Wang ${ }^{3}$, Junwei Zhao ${ }^{3}$, Feiyu Jia ${ }^{3}$, Lingyu Yang ${ }^{3}$, \\ Deguang Yang ${ }^{2}$ and Wensheng Xiang ${ }^{3,4}$
}

A novel actinomycete, designated strain NEAU-gq9 ${ }^{\top}$, was isolated from corn root (Zea mays L.) and characterized using a polyphasic approach. The organism was found to have morphological and chemotaxonomic characteristics typical of the genus Micromonospora. On the basis of $16 \mathrm{~S}$ rRNA gene sequence similarity studies, strain NEAU-gq9 ${ }^{\top}$ was most closely related to Micromonospora zamorensis CR38 ${ }^{\top}$ (99.3\%), Micromonospora jinlongensis NEAU-GRX11 ${ }^{\top}(99.2 \%)$, Micromonospora saelicesensis Lupac $09^{\top}(99.2 \%)$, Micromonospora chokoriensis $2-19(6)^{\top}(98.9 \%)$, Micromonospora coxensis $2-30-\mathrm{b}(28)^{\top}$ (98.6\%) and Micromonospora lupini Lupac $14 \mathrm{~N}^{\top}$ (98.5\%). Phylogenetic analysis based on the 16S rRNA gene and gyrB gene demonstrated that strain NEAU-gq ${ }^{\top}$ is a member of the genus Micromonospora and supported the closest phylogenetic relationship to $M$. zamorensis CR38 ${ }^{\top}$, M. jinlongensis NEAU-GRX11 ${ }^{\top}, M$. saelicesensis Lupac $09^{\top}, M$. chokoriensis 2-19(6) ${ }^{\top}$ and M. Iupini Lupac $14 \mathrm{~N}^{\top}$. A combination of DNA-DNA hybridization, morphological and physiological characteristics indicated that the novel strain could be readily distinguished from the closest phylogenetic relatives. Therefore, it is proposed that strain NEAU-gq9 ${ }^{\top}$ represents a novel species of the genus Micromonospora, for which the name Micromonospora zeae sp. nov. is proposed. The type strain is NEAU-gq9 ${ }^{\top}\left(=\right.$ CGMCC $^{4} .7092^{\top}=$ DSM $\left.45882^{\top}\right)$.

The Journal of Antibiotics (2014) 67, 739-743; doi:10.1038/ja.2014.54; published online 21 May 2014

\section{INTRODUCTION}

Micromonospora proposed by $\emptyset_{\text {rskov }}{ }^{1}$ is the type genus of the family Micromonosporaceae and has gradually been recognized as an important source of secondary metabolites. ${ }^{2}$ Many antibiotics, such as gentamicin, netamicin, lomaiviticins $\mathrm{A}$ and $\mathrm{B}$, tetrocarcin $\mathrm{A}$ and diazepinomicin have been isolated from this genus. ${ }^{2,3}$ Thus, their impact on medicine is considerable. Endophytic Micromonospora species have recently been reviewed with respect to their broad distribution and their potential for use as probiotics. ${ }^{4}$ In the last few years, six novel endophytic species of genus Micromonospora were isolated from different plants, including M. coriariae, $^{5}$ M. lupini, ${ }^{6}$ M. saelicesensis, ${ }^{6}$ M. pisi, ${ }^{7}$ M. avicenniae ${ }^{8}$ and M. sonneratiae. ${ }^{9}$ Two novel anthraquinones, lupinacidins $\mathrm{A}$ and $\mathrm{B}$ with significant antitumor activity were isolated from $M$. lupini. ${ }^{10}$ As part of a program to discover actinomycetes with novel antibiotic production properties, strain NEAU-gq $9^{\mathrm{T}}$ was isolated from corn root (Zea mays L.). In this study, the taxonomic status of this strain is reported on the basis of phylogenetic and phenotypic evidences. It is proposed that strain NEAU-gq $9^{\mathrm{T}}$ is a new species of the genus Micromonospora, for which the name Micromonospora zeae sp. nov. is proposed.

\section{MATERIALS AND METHODS}

Isolation and cultivation

Strain NEAU-gq $9^{\mathrm{T}}$ was isolated from corn root (Zea mays L.) collected from Harbin, Heilongjiang province, North China $\left(45^{\circ} 45^{\prime} \mathrm{N}, 126^{\circ} 41^{\prime} \mathrm{E}\right)$. The corn root was tagged outdoors and stored in a clean plastic bag until used $(\sim 24 \mathrm{~h})$. The root sample was air dried for $24 \mathrm{~h}$ at room temperature and then washed in water with an ultrasonic step (160 W, $15 \mathrm{~min}$ ) (KH-160TDV, Hechuang, China) to remove the surface soils and adherent epiphytes completely. After drying, the sample was cut into pieces of $5-10 \mathrm{~mm}$ in length and then subjected to a seven-step surface sterilization procedure: a 60 -second wash in sterile tap water containing cycloheximide $\left(100 \mathrm{mgl}^{-1}\right)$ and nalidixic acid $\left(20 \mathrm{mgl}^{-1}\right)$, followed by a wash in sterile water, a 5 -min wash in $5 \%(\mathrm{v} / \mathrm{v})$ $\mathrm{NaOCl}$, a $10-$ min wash in $2.5 \%(\mathrm{w} / \mathrm{v}) \mathrm{Na}_{2} \mathrm{~S}_{2} \mathrm{O}_{3}$, a 5 -min wash in $75 \%(\mathrm{v} / \mathrm{v})$ ethanol, a wash in sterile water and a final rinse in $10 \%(\mathrm{w} / \mathrm{v}) \mathrm{NaHCO}_{3}$ for $10 \mathrm{~min}$. After being thoroughly dried under sterile conditions, the surfacesterilized samples were subjected to continuous drying at $100^{\circ} \mathrm{C}$ for $15 \mathrm{~min}$. The sample was then cut up in a commercial blender and ground with a mortar and pestle, employing $1 \mathrm{ml}$ of $0.5 \mathrm{M}$ potassium phosphate buffer $(\mathrm{pH}$ 7.0) per $100 \mathrm{mg}$ tissue. Tissue particles were allowed to settle down at $4{ }^{\circ} \mathrm{C}$ for 20-30 min, and the supernatant was spread on a plate of humic acid-vitamin agar $^{11}$ supplemented with cycloheximide $\left(50 \mathrm{mgl}^{-1}\right)$ and nalidixic acid $\left(20 \mathrm{mgl}^{-1}\right)$. After 21 days of aerobic incubation at $28^{\circ} \mathrm{C}$, colonies were

${ }^{1}$ College of Science, Northeast Agricultural University, Harbin, China; ${ }^{2}$ College of Agriculture, Northeast Agricultural University, Harbin, China; ${ }^{3}$ Key Laboratory of Agriculture Biological Functional Gene of Heilongjiang Provincial Education Committee, Northeast Agricultural University, Harbin, China and ${ }^{4}$ State Key Laboratory for Biology of Plant Diseases and Insect Pests, Institute of Plant Protection, Chinese Academy of Agricultural Sciences, Beijing, China

${ }^{5}$ These authors contributed equally to this work.

Correspondence: Professor D Yang, College of Agriculture, Northeast Agricultural University, No. 59 Mucai Street, Xiangfang District, Harbin 150030, China. E-mail: deguangyang@sina.com

or Professor W Xiang, Key Laboratory of Agriculture Biological Functional Gene of Heilongjiang Provincial Education Committee, Northeast Agricultural University, No. 59 Mucai Street, Xiangfang District, Harbin 150030, China.

E-mail: xiangwensheng@neau.edu.cn

Received 7 November 2013; revised 2 April 2014; accepted 7 April 2014; published online 21 May 2014 
transferred and purified on International Streptomyces Project (ISP) medium $3^{12}$ and incubated at $28^{\circ} \mathrm{C}$ for $2-3$ weeks.

\section{Morphological and physiological characteristics}

Morphological properties were observed by light microscopy (Nikon ECLIPSE E200, Japan) and scanning electron microscopy (Hitachi S-3400N, Japan) using cultures grown on ISP 3 agar for 2 weeks at $28^{\circ} \mathrm{C}$. Cultural characteristics were determined by growth on $\mathrm{SAl}$ agar, ${ }^{13} \mathrm{~N}-\mathrm{Z}$ amine agar, Bennett's agar ${ }^{14}$ and ISP media $2-7^{12}$ at $28^{\circ} \mathrm{C}$ for 2 weeks. The ISCC-NBS color charts were used to determine the names and designations of colony colors. ${ }^{15}$ Growth at different temperatures $\left(4,16,18,22,28,37,45^{\circ} \mathrm{C}\right)$ was determined on ISP 3 agar after incubation for 2 weeks. $\mathrm{pH}$ range ( $\mathrm{pH} 4,5,6,7$, $8,9,10)$ and $\mathrm{NaCl}$ tolerance $(0,1,2,3,4,5,6,7$ and $8 \%, w / v)$ for growth were determined on GY medium ${ }^{16}$ in shake flasks $\left(250\right.$ r.p.m.) at $28^{\circ} \mathrm{C}$ for 7 days. Nitrate reduction, starch hydrolysis, milk coagulation, cellulose decomposition, gelatin liquefaction, production of $\mathrm{H}_{2} \mathrm{~S}$ and catalase, degradation of urea and aesculin were examined as described by Gordon et al. ${ }^{17}$ Utilization of sole carbon source was tested on ISP 9 medium. ${ }^{12}$ Utilization of amino acids as nitrogen sources was tested as described by Williams et al. ${ }^{18}$

\section{Chemotaxonomic analysis}

The freeze-dried cells used for chemotaxonomic analysis were obtained from cultures grown in GY medium on a rotary shaker for 7 days at $28^{\circ} \mathrm{C}$. Cells were harvested by centrifugation, washed with distilled water and freeze-dried. The isomers of diaminopimelic acid in peptidoglycan were analyzed by a HPLC method using Agilent TC- $\mathrm{C}_{18}$ Column $(250 \times 4.6 \mathrm{~mm}$ i.d. $5 \mu \mathrm{m})$ (USA) with a mobile phase consisting of acetonitrile: $0.05 \mathrm{moll}^{-1}$ phosphate buffer $\mathrm{pH} 7.2(15: 85, \mathrm{v} / \mathrm{v})$ at a flow rate of $0.5 \mathrm{ml} \mathrm{min}^{-1}$. The peak detection used was an Agilent G1321A fluorescence detector with a $365 \mathrm{~nm}$ excitation and $455 \mathrm{~nm}$ longpass emission filters. ${ }^{19}$ The whole-organism sugars were analyzed according to the procedures developed by Lechevalier and Lechevalier. ${ }^{20}$ Phospholipids in cells were examined by two-dimensional TLC and identified using the method of Minnikin et al. ${ }^{21}$ Menaquinones were extracted from freeze-dried biomass and purified according to Collins. ${ }^{22}$ The extracts were analyzed by a HPLC-UV method using an Agilent Extend- $\mathrm{C}_{18}$ Column $(150 \times 4.6 \mathrm{~mm}$, i.d. $5 \mu \mathrm{m})$, typically at $270 \mathrm{~nm}$. The mobile phase was acetonitrile-propyl alcohol $(60: 40, \mathrm{v} / \mathrm{v})$ and the flow rate was set to $1.0 \mathrm{ml} \mathrm{min}^{-1}$ and the run time was $60 \mathrm{~min}$. The injection volume was $20 \mu \mathrm{l}$, and the chromatographic column was controlled at $40{ }^{\circ} \mathrm{C} .{ }^{23}$ Mycolic acids were checked by the acid methanolysis method as described previously. ${ }^{24}$ Biomass for fatty acids analysis was obtained by growing strain NEAU-gq $9^{\mathrm{T}}$ in GY medium on a rotary shaker for 5 days at $28^{\circ} \mathrm{C}$ and the fatty acids were analyzed by GC-MS using the method of Gao et al. ${ }^{25}$

\section{Phylogenetic analysis}

Extraction of chromosomal DNA and PCR-mediated amplification of the $16 \mathrm{~S}$ rRNA gene were carried out using a standard procedure. ${ }^{26}$ The PCR product was purified and cloned into the pMD19-T (Takara, Dalian, China) vector and sequenced by using an Applied Biosystems DNA sequencer (model 3730XL) and software provided by the manufacturer. Almost full-length 16S rRNA gene sequence $(1510 \mathrm{nt})$ was obtained and aligned with multiple sequences obtained from the GenBank/EMBL/DDBJ databases using Clustal X 1.83 software. Phylogenetic trees were generated with the neighbor-joining ${ }^{27}$ and maximumlikelihood algorithms ${ }^{28}$ using Molecular Evolutionary Genetics Analysis software version $5.05 .^{29}$ The stability of the clades in the trees was appraised using a bootstrap value with 1000 repeats. ${ }^{30} \mathrm{~A}$ distance matrix was generated using the Kimura's two-parameter model. ${ }^{31}$ All positions containing gaps and missing data were eliminated from the data set (complete deletion option). $16 \mathrm{~S}$ rRNA gene sequence similarities between the type strains were calculated on the basis of pairwise alignment using the EzTaxon-e server. ${ }^{32}$ PCR amplification of the $g y r B$ gene sequence (1162 nt) was carried out using primers GYF1 and GYR3B ${ }^{33}$ by the PCR program for $16 \mathrm{~S}$ rRNA gene. Sequencing and phylogenetic analysis of $\operatorname{gyr} B$ gene were performed as described above. Actinoplanes regularis IFO $12514^{\mathrm{T}}$ was used as an outgroup. The $\mathrm{G}+\mathrm{C}$ content of the genomic DNA was determined by the thermal denaturation method as described by Mandel and Marmur, ${ }^{34}$ and Escherichia coli JM109 was used as the reference strain. DNA-DNA relatedness tests between strain NEAU-gq9 ${ }^{\mathrm{T}}$ and Micromonospora zamorensis CR $38^{\mathrm{T}}$, Micromonospora jinlongensis NEAU-GRX11 ${ }^{\mathrm{T}}$, Micromonospora saelicesensis Lupac $09^{\mathrm{T}}$, Micromonospora chokoriensis $2-19(6)^{\mathrm{T}}$ and Micromonospora lupini Lupac $14 \mathrm{~N}^{\mathrm{T}}$ were carried out as described by De Ley et al..$^{35}$ under consideration of the modifications described by Huss et al. ${ }^{36}$ using a model Cary 100 Bio UV/ VIS-spectrophotometer equipped with a Peltier-thermostatted $6 \times 6$ multicell changer and a temperature controller with an in-situ temperature probe (Varian).

\section{RESULTS AND DISCUSSION}

\section{Morphological and physiological characteristics}

The morphological and cultural properties of strain NEAU-gq $9^{\mathrm{T}}$ are consistent with its classification as a member of the genus Micromonospora. Strain NEAU-gq9 ${ }^{\mathrm{T}}$ produced well-developed and branched substrate hyphae on ISP 3 medium. Nonmotile and oval spores $(0.56-0.66 \times 0.61-0.71 \mu \mathrm{m})$ were borne singly on the substrate mycelium and the spore surface was smooth (Figure 1). The novel isolate showed good growth on SA1, Bennett's, ISP 2, ISP 3 and ISP 6 agar, moderate growth on $\mathrm{N}-\mathrm{Z}$ amine, ISP 4 and ISP 7 agar, and no growth on ISP 5 agar. Aerial mycelia were not detected on any of the tested media. The substrate mycelium of strain NEAU-gq $9^{\mathrm{T}}$ varied from orange to blackish red on all media tested (Supplementary Table S1). No diffusible pigment was detected. Strain NEAU-gq $9^{\mathrm{T}}$ was observed to grow well between $\mathrm{pH}$ 6.0-9.0, with an optimum $\mathrm{pH}$ of 7.0. The range of temperature was determined to be $18-37^{\circ} \mathrm{C}$, with the optimum growth temperature at $28^{\circ} \mathrm{C}$. Strain NEAU-gq $9^{\mathrm{T}}$ was observed to grow in the presence of $0-3 \% \mathrm{NaCl}$ $(\mathrm{w} / \mathrm{v})$. Detailed physiological characteristics are presented in the species description.

\section{Chemotaxonomic characteristics}

Chemotaxonomic characteristics of strain NEAU-gq $9^{\mathrm{T}}$ also supported its classification as a member of the genus Micromonospora. Cells of strain NEAU-gq $9^{\mathrm{T}}$ were observed to contain meso-diaminopimelic acid and glycine as diagnostic amino acids. Whole-cell hydrolysates were found to contain xylose and glucose. The major menaquinones detected were MK-10 $\left(\mathrm{H}_{2}\right)(42.3 \%)$, MK-10 $\left(\mathrm{H}_{4}\right)(37.2 \%)$, MK-8 $\left(\mathrm{H}_{8}\right)$ $(13.7 \%)$ and MK-9 $\left(\mathrm{H}_{4}\right)(6.8 \%)$. The phospholipid profile was found to consist of diphosphatidylglycerol, phosphatidylethanolamine and phosphatidylinositol (Supplementary Figure S1). The cellular fatty acid profile was determined to be composed of $\mathrm{C}_{16: 0}(35.1 \%)$, $\mathrm{C}_{17: 1} \omega 7 \mathrm{c}(19.0 \%), \mathrm{C}_{15: 0}$ (14.1\%), $\mathrm{C}_{18: 0}$ (7.4\%), $\mathrm{C}_{17: 0}$ 10-methyl (5.7\%), anteiso- $\mathrm{C}_{17: 0}(4.5 \%), \mathrm{C}_{18: 1} \omega 7 \mathrm{c}(4.2 \%), \mathrm{C}_{16: 1} \omega 7 \mathrm{c}(2.7 \%)$,

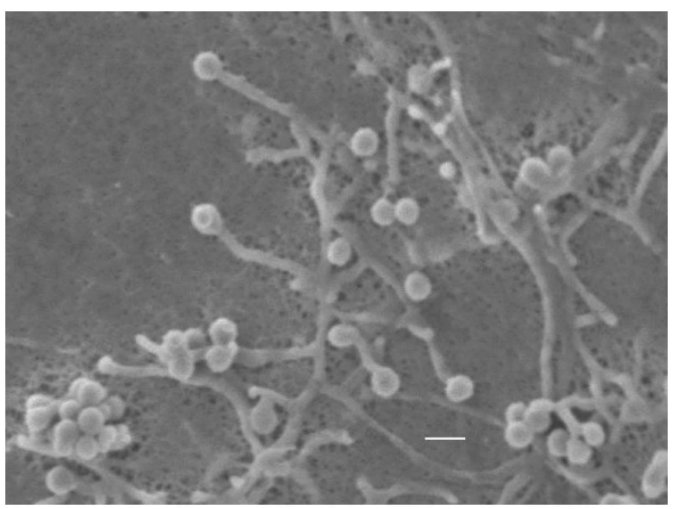

Figure 1 Scanning electron micrograph of spores on substrate mycelium of strain NEAU-gq9 $9^{\top}$ grown on ISP 3 agar for 2 weeks at $28^{\circ} \mathrm{C}$. Bar, $1 \mu \mathrm{m}$. 
$\mathrm{C}_{17: 0}(2.4 \%)$, iso- $\mathrm{C}_{17: 0}(1.5 \%), \mathrm{C}_{18: 1} \omega 5 \mathrm{c}$ (1.2\%), $\mathrm{C}_{18: 0}$ 10-methyl $(1.0 \%)$, iso- $\mathrm{C}_{14: 0}(0.6 \%), \mathrm{C}_{14: 0}(0.6 \%)$ and $\mathrm{C}_{17: 1} \omega 8 \mathrm{c}(0.6 \%)$. The low proportions of iso-branched fatty acids were different from most Micromonospora species, but consistent with the description by Gao et al. $^{25}$ and Li et al. ${ }^{37}$ Mycolic acids were not detected. The $\mathrm{G}+\mathrm{C}$ content of the DNA was $68.8 \pm 0.3 \mathrm{~mol} \%$.

\section{Phylogenetic characteristics}

The almost-complete $16 \mathrm{~S}$ rRNA gene sequence $(1510 \mathrm{nt})$ of strain NEAU-gq ${ }^{\mathrm{T}}$ was determined and deposited as KC287242 in the GenBank/EMBL/DDBJ databases. On the basis of EzTaxon-e analysis, the species most closely related to the novel isolate were M. zamorensis CR38 ${ }^{\mathrm{T}}(99.3 \%), M$. jinlongensis NEAU-GRX $11^{\mathrm{T}}$ (99.2\%), M. saelicesensis Lupac $09^{\mathrm{T}}(99.2 \%), \quad$ M. chokoriensis $2-19(6)^{\mathrm{T}}(98.9 \%)$, M. coxensis $2-30-\mathrm{b}(28)^{\mathrm{T}}(98.6 \%)$ and M. lupini Lupac $14 \mathrm{~N}^{\mathrm{T}}(98.5 \%)$. The phylogenetic tree (Figure 2) based on $16 \mathrm{~S}$ rRNA gene sequences showed that strain NEAU-gq $9^{T}$ formed a distinct phyletic line with $M$. zamorensis $\mathrm{CR} 38^{\mathrm{T}}, M$. jinlongensis NEAU-GRX11 ${ }^{\mathrm{T}}$, M. saelicesensis Lupac $09^{\mathrm{T}}$, M. chokoriensis $2-19(6)^{\mathrm{T}}$ and M. lupini Lupac $14 \mathrm{~N}^{\mathrm{T}}$, an association that was supported by maximum-likelihood algorithm employed and by a $78 \%$ bootstrap value in the neighbor-joining analysis. The similarities of $\operatorname{gyrB}$ gene

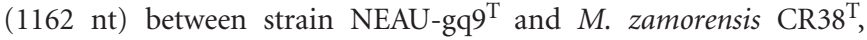
M. jinlongensis NEAU-GRX11 ${ }^{\mathrm{T}}, M$. saelicesensis Lupac $09^{\mathrm{T}}$, M. chokoriensis $2-19(6)^{\mathrm{T}}$ and M. lupini Lupac $14 \mathrm{~N}^{\mathrm{T}}$ were $98.6 \%$, $98.4 \%, 96.7 \%, 95.5 \%$ and $97.6 \%$, respectively. Phylogenetic analysis of $g y r B$ gene sequence supported that strain NEAU-gq $9^{\mathrm{T}}$ was placed in the genus Micromonospora, also near to M. zamorensis CR $38^{\mathrm{T}}$, M. jinlongensis NEAU-GRX11 ${ }^{\mathrm{T}}, M$. saelicesensis Lupac $09^{\mathrm{T}}$, M. chokoriensis $2-19(6)^{\mathrm{T}}$ and M. lupini Lupac $14 \mathrm{~N}^{\mathrm{T}}$ by a $78 \%$ bootstrap value (Supplementary Figure S2).

Further study showed that the DNA relatedness values between strain NEAU-gq $9^{\mathrm{T}}$ and $M$. zamorensis $\mathrm{CR} 38^{\mathrm{T}}, M$. jinlongensis NEAUGRX11 ${ }^{\mathrm{T}}$, M. saelicesensis Lupac $09^{\mathrm{T}}$, M. chokoriensis $2-19(6)^{\mathrm{T}}$ and $M$. lupini Lupac $14 \mathrm{~N}^{\mathrm{T}}$ were $51.8 \pm 1.8,41.3 \pm 2.2,48.5 \pm 0.8,53.0 \pm 1.8 \%$ and $43.4 \pm 2.9 \%$, respectively. These values were below the threshold value of $70 \%$ recommended by Wayne et al. ${ }^{38}$ for assigning strains to the same genomic species. In addition, a comparative study between strain NEAU-gq $9^{\mathrm{T}}$ and the five related Micromonospora type strains revealed that it differed from them in morphological, physiological and biochemical characteristics as summarized in Table 1 and Supplementary Figure S3. Therefore, strain NEAU-gq $9^{\mathrm{T}}$ represents a novel species of the genus Micromonospora, for which the name Micromonospora zeae sp. nov. is proposed.

\section{Description of Micromonospora zeae sp. nov.}

Micromonospora zeae (ze.ae. N.L. masc. n. Zea, botanical genus name; N.L. gen. n. zeae, of Zea, referring to the isolation of the organism from Zea mays L.).

Micromonospora zeae sp. nov. is aerobic, Gram-staining-positive actinomycete that forms well-developed and branched substrate hyphae. Colonies are orange color-series. No diffusible pigment is detected on any of the tested media. Single, nonmotile and oval spores $(0.56-0.66 \times 0.61-0.71 \mu \mathrm{m})$ with a smooth surface are produced. M. zeae is positive for gelatin liquefaction, aesculin hydrolysis, production of catalase; and negative for starch hydrolysis, milk coagulation, nitrate reduction, cellulose decomposition, urea degradation and production of $\mathrm{H}_{2} \mathrm{~S}$. L-arabinose, D-fructose, D-galactose, D-glucose, lactose, D-maltose, D-mannose, D-mannitol, D-raffinose, L-rhamnose, D-sucrose and D-xylose are utilized as sole carbon sources but inositol, D-ribose and D-sorbitol are not utilized.

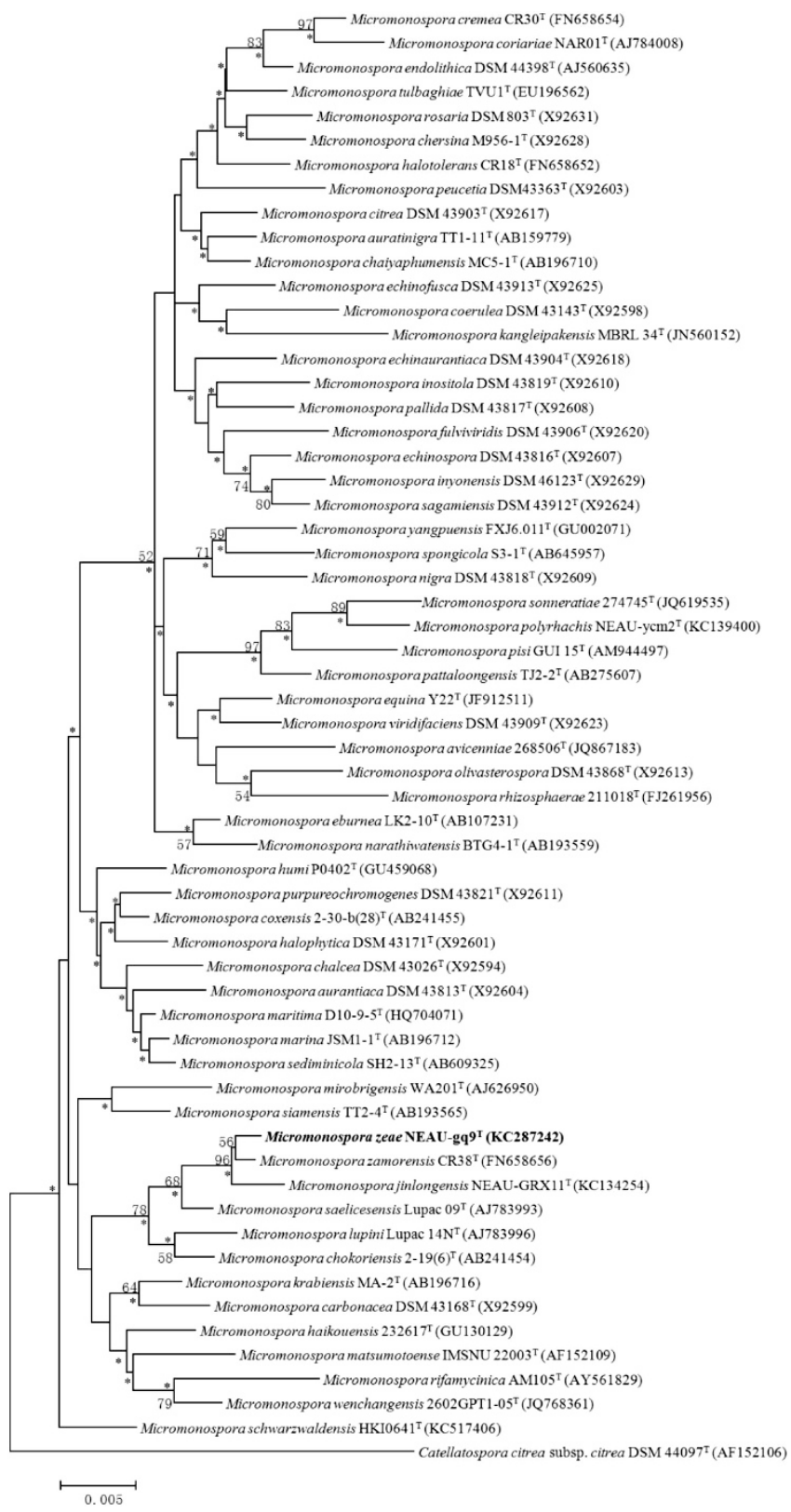

Figure 2 Neighbor-joining phylogenetic tree showing the position of strain NEAU-gq9 ${ }^{\top}$ (1510 nt) and the type strains of all other members of the genus Micromonospora based on 16S rRNA gene sequences. Catellatospora citrea subsp. citrea DSM $44097^{\top}$ was used as an outgroup. Asterisks $\left(^{*}\right)$ indicate branches of the tree that were also recovered using the maximum-likelihood method. Bootstrap values $>50 \%$ (based on 1000 replications) are shown at branch points. Bar, 0.005 substitutions per nucleotide position.

L-alanine, L-arginine, L-aspartic acid, L-asparagine, creatine, L-glutamine, L-serine, L-threonine and L-tyrosine are utilized as sole nitrogen sources but glycine and L-glutamic acid are not utilized. Tolerates up to $3 \% \mathrm{NaCl}$ and grows at temperatures between 18 and $37^{\circ} \mathrm{C}$, with an optimum temperature of $28^{\circ} \mathrm{C}$. Growth occurs at initial $\mathrm{pH}$ values between 6.0 and 9.0, the optimum being $\mathrm{pH}$ 7.0. The predominant menaquinones are MK-10 $\left(\mathrm{H}_{2}\right)$ and $\mathrm{MK}-10\left(\mathrm{H}_{4}\right)$. The major fatty acids $(>10 \%)$ are $\mathrm{C}_{16: 0}, \mathrm{C}_{17: 1} \omega 7 \mathrm{c}$ and $\mathrm{C}_{15: 0}$. The $\mathrm{G}+\mathrm{C}$ content of the DNA is $68.8 \pm 0.3 \mathrm{~mol} \%$. The type strain is NEAU-gq $9^{\mathrm{T}}$ (=CGMCC $\left.4.7092^{\mathrm{T}}=\mathrm{DSM} 45882^{\mathrm{T}}\right)$, which was isolated from corn root (Zea 
Table 1 Differential characteristics of strain NEAU-gq9 ${ }^{\top}$ and the closest related Micromonospora species

\begin{tabular}{|c|c|c|c|c|c|c|}
\hline Characteristics & 1 & 2 & 3 & 4 & 5 & 6 \\
\hline \multicolumn{7}{|c|}{ Color of streak plating/diffusible pigments on } \\
\hline ISP 3 & Blackish red/none & Deep brown/none & $\begin{array}{l}\text { Very dark purple/ } \\
\text { deep purple }\end{array}$ & $\begin{array}{l}\text { Dark red/ moderate } \\
\text { reddish orange }\end{array}$ & $\begin{array}{l}\text { Moderate brown/ } \\
\text { none }\end{array}$ & $\begin{array}{l}\text { Brilliant orange } \\
\text { yellow/none }\end{array}$ \\
\hline ISP 7 & $\begin{array}{l}\text { Moderate brown/ } \\
\text { none }\end{array}$ & $\begin{array}{l}\text { Moderate orange/ } \\
\text { brownish orange }\end{array}$ & Strong violet/none & $\begin{array}{l}\text { Light orange yellow/ } \\
\text { none }\end{array}$ & Light brown/none & $\begin{array}{l}\text { Light orange } \\
\text { yellow/none }\end{array}$ \\
\hline SA1 & Vivid orange/none & Strong brown/none & $\begin{array}{l}\text { Moderate brown/ } \\
\text { moderate violet }\end{array}$ & $\begin{array}{l}\text { Moderate orange/ } \\
\text { none }\end{array}$ & $\begin{array}{l}\text { Dark brown/deep } \\
\text { brown }\end{array}$ & $\begin{array}{l}\text { Light orange/ } \\
\text { light orange }\end{array}$ \\
\hline $\begin{array}{l}\text { Cellulose } \\
\text { decomposition }\end{array}$ & - & - & - & + & + & + \\
\hline $\begin{array}{l}\text { Production of } \\
\text { catalase }\end{array}$ & + & + & + & + & - & - \\
\hline \multicolumn{7}{|c|}{ Use as sole nitrogen source: } \\
\hline L-threonine & + & + & + & + & - & + \\
\hline L-glutamic acid & - & - & + & + & - & - \\
\hline \multicolumn{7}{|c|}{ Use as sole carbon source: } \\
\hline D-raffinose & + & - & + & + & + & + \\
\hline D-mannitol & + & - & + & - & + & - \\
\hline D-fructose & + & - & - & + & + & + \\
\hline
\end{tabular}

Abbreviation: ISP, International Streptomyces Project.

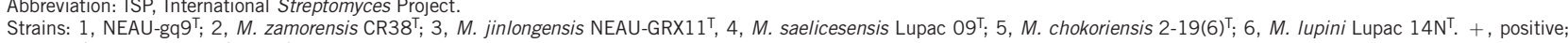
,- negative. All data are from this study.

mays L.). The GenBank/EMBL/DDBJ accession numbers for the $16 \mathrm{~S}$ rRNA gene and $g y r B$ gene of strain NEAU-gq $9^{\mathrm{T}}$ are KC287242 and KF053533, respectively.

\section{ACKNOWLEDGEMENTS}

This work was supported in part by grants from the National Outstanding Youth Foundation (No. 31225024), the National Key Project for Basic Research (No. 2010CB126102), the National Key Technology R\&D Program (No. 2012BAD19B06), the Program for New Century Excellent Talents in University (NCET-11-0953), the National Natural Science Foundation of China (No.31372006, 31171913 and 31071750), the Outstanding Youth Foundation of Heilongjiang Province (JC201201) and Chang Jiang Scholar Candidates Program for Provincial Universities in Heilongjiang (CSCP).

$1 \varnothing$ rskov, J. Investigations into the morphology of the ray fungi (Levin and Munksgaard, Enhagen, 1923).

2 Bérdy, J. Bioactive microbial metabolites. J. Antibiot. 58, 1-26 (2005).

3 Charan, R. D. et al. Diazepinomicin, a new antimicrobial alkaloid from a marine Micromonospora sp. J. Nat. Prod. 67, 1431-1433 (2004).

4 Hirsch, A. M. \& Valdés, M. Micromonospora: an important microbe for biomedicine and potentially for biocontrol and biofuels. Soil Biol. Biochem. 42, 536-542 (2010).

5 Trujillo, M. E., Kroppenstedt, R. M., Schumann, P., Carro, L. \& Martínez-Molina, E. Micromonospora coriariae sp. nov., isolated from root nodules of Coriaria myrtifolia. Int. J. Syst. Evol. Microbiol. 56, 2381-2385 (2006).

6 Trujillo, M. E., Kroppenstedt, R. M., Fernández-Molinero, C., Schumann, P. \& Martínez-Molina, E. Micromonospora Iupini sp. nov. and Micromonospora saelicesensis sp. nov., isolated from root nodules of Lupinus angustifolius. Int. J. Syst. Evol. Microbiol. 57, 2799-2804 (2007).

7 Garcia, L. C., Martínez-Molina, E. \& Trujillo, M. E. Micromonospora pisi sp. nov. isolated from root nodules of Pisum sativum. Int. J. Syst. Evol. Microbiol. 60, 331-337 (2010).

8 Li, L., Mao, Y. J., Xie, Q. Y., Deng, Z. \& Hong, K. Micromonospora avicenniae sp. nov., isolated from a root of Avicennia marina. Antonie Van Leeuwenhoek 103, 1089-1096 (2013a).

$9 \mathrm{Li}$, L. et al. Micromonospora sonneratiae sp. nov., isolated from a root of Sonneratia apetala. Int. J. Syst. Evol. Microbiol. 63, 2383-2388 (2013b).
10 Igarashi, Y. et al. Antitumor anthraquinones from an endophytic actinomycete Micromonospora lupini sp. nov. Bioorg. Med. Chem. Lett. 17, 3702-3705 (2007).

11 Hayakawa, M. \& Nonomura, H. Humic acid-vitamin agar, a new medium for the selective isolation of soil actinomycetes. J. Ferment. Technol. 65, 501-509 (1987).

12 Shirling, E. B. \& Gottlieb, D. Methods for characterization of Streptomyces species. Int. J. Syst. Bacteriol. 16, 313-340 (1966).

13 Trujillo, M. E. et al. Micromonospora mirobrigensis sp. nov. Int. J. Syst. Evol. Microbiol. 55, 877-880 (2005).

14 Jones, K. L. Fresh isolates of actinomycetes in which the presence of sporogenous aerial mycelia is a fluctuating characteristic. J. Bacteriol. 57, 141-145 (1949).

15 Kelly, K. L. Inter-Society Color Council-National Bureau of Standards Color Name Charts Illustrated with Centroid Colors (US Government Printing Office, Washington, DC, 1964).

$16 \mathrm{Jia}, \mathrm{F}$. Y. et al. Wangella harbinensis gen. nov., sp. nov., a new member of the family Micromonosporaceae. Antonie Van Leeuwenhoek 103, 399-408 (2013).

17 Gordon, R. E., Barnett, D. A., Handerhan, J. E. \& Pang, C. Nocardia coeliaca, Nocardia autotrophica, and the nocardin strain. Int. J. Syst. Bacteriol. 24, 54-63 (1974).

18 Williams, S. T. et al. Numerical classification of Streptomyces and related genera. J. Gen. Microbiol. 129, 1743-1813 (1983).

19 McKerrow, J. et al. A simple HPLC method for analysing diaminopimelic acid diastereomers in cell walls of Gram-positive bacteria. Lett. Appl. Microbiol. 30, 178-182 (2000).

20 Lechevalier, M. P. \& Lechevalier, H. A. In: Actinomycete taxonomy special publication, vol 6 (eds Dietz, A. \& Thayer, D. W.) pp 227-291 (Society of Industrial Microbiology, Arlington, 1980).

21 Minnikin, D. E. et al. An integrated procedure for the extraction of bacterial isoprenoid quinones and polar lipids. J. Microbiol. Methods 2, 233-241 (1984).

22 Collins, M. D. In: Chemical Methods in Bacterial Systematics (eds Goodfellow, M. \& Minnikin, D. E.) pp 267-284 (Academic Press, London, 1985).

23 Wu, C., Lu, X., Qin, M., Wang, Y. \& Ruan, J. Analysis of menaquinone compound in microbial cells by HPLC. Microbiology [English translation of Microbiology (Beijing)] 16, 176-178 (1989).

24 Minnikin, D. E., Hutchinson, I. G., Caldicott, A. B. \& Goodfellow, M. Thin-layer chromatography of methanolysates of mycolic acid-containing bacteria. J. Chromatogr. 188, 221-233 (1980).

$25 \mathrm{Gao}, \mathrm{R} . \mathrm{X}$. et al. Micromonospora jinlongensis sp. nov., isolated from muddy soil in China and emended description of the genus Micromonospora.. Antonie Van Leeuwenhoek 105, 307-315 (2014).

$26 \mathrm{Kim}, \mathrm{S}$. B. et al. Gordonia amicalis sp. nov., a novel dibenzothiophene-desulphurizing actinomycete. Int. J. Syst. Evol. Microbiol. 50, 2031-2036 (2000).

27 Saitou, N. \& Nei, M. The neighbor-joining method: a new method for reconstructing phylogenetic trees. Mol. Biol. Evol. 4, 406-425 (1987).

28 Felsenstein, J. Evolutionary trees from DNA sequences: a maximum likelihood approach. J. Mol. Evol. 17, 368-376 (1981). 
29 Tamura, K. et al. MEGA5: Molecular Evolutionary Genetics Analysis using maximum likelihood, evolutionary distance, and maximum parsimony methods. Mol. Biol. Evol. 28, 2731-2739 (2011).

30 Felsenstein, J. Confidence limits on phylogenies: an approach using the bootstrap. Evolution 39, 783-791 (1985).

31 Kimura, M. A simple method for estimating evolutionary rates of base substitutions through comparative studies of nucleotide sequences. J. Mol. Evol. 16, 111-120 (1980).

$32 \mathrm{Kim}$, O. S. et al. Introducing EzTaxon-e: a prokaryotic 16S rRNA gene sequence database with phylotypes that represent uncultured species. Int. J. Syst. Evol. Microbiol. 62, 716-721 (2012)

33 Garcia, L. C., Martínez-Molina, E. \& Trujillo, M. E. Micromonospora pisi sp. nov., isolated from root nodules of Pisum sativum. Int. J. Syst. Evol. Microbiol. 60, 331-337 (2010).
34 Mandel, M. \& Marmur, J. Use of ultraviolet absorbance temperature profile for determining the guanine plus cytosine content of DNA. Methods Enzymol. 12B, 195-206 (1968).

35 De Ley, J., Cattoi, H. \& Reynaerts, A. The quantitative measurement of DNA hybridization from renaturation rates. Eur. J. Biochem. 12, 133-142 (1970).

36 Huss, V. A. R., Festl, H. \& Schleifer, K. H. Studies on the spectrometric determination of DNA hybridisation from renaturation rates. Syst. Appl. Microbiol. 4, 184-192 (1983).

$37 \mathrm{Li}$, C. et al. (2013)Micromonospora maoerensis sp. nov., isolated from a Chinese pine forest soil. Antonie Van Leeuwenhoek 105, 451-459 (2014).

38 Wayne, L. G. et al. International Committee on Systematic Bacteriology. Report of the ad hoc committee on reconciliation of approaches to bacterial systematics. Int. J. Syst. Bacteriol. 37, 463-464 (1987).

Supplementary Information accompanies the paper on The Journal of Antibiotics website (http://www.nature.com/ja) 